\title{
PROFIL KEMAMPUAN LITERASI STATISTIS MAHASISWA JURUSAN PENDIDIKAN MATEMATIKA UNIVERSITAS SULTAN AGENG TIRTAYASA
}

\author{
Etika Khaerunnisa ${ }^{1}$, Aan Subhan Pamungkas ${ }^{2}$ \\ ${ }^{1,2}$ Universitas Sultan Ageng Tirtayasa \\ Email: etika_kh@untirta.ac.id ${ }^{1)}$ \\ aansubhanp@gmail.com ${ }^{2}$
}

\begin{abstract}
As an effort to achieve meaningfulness in the research process conducted by students, it requires a student ability covering ability compile to with refer to the question to be researched, formulating statistical hypothesis, solving, and interpreting problems which is relied by existing context, this ability is known as statistical literacy. The purpose of this study is to describe and assess the ability of statistical literacy. By knowing the ability of statistical literacy early on in the first semester, it will be able to be developed furthermore realization of subject circumstances under study in further statistics. The method used in this research is qualitative method with type of research strategy of case study. The subjects of the study are students majoring in mathematics education semester I in the basic statistics courses of the academic year 2016/2017. Research instrument is researcher as main instrument, and statistic literacy test. The result of the research is 35\% of students are in the high statistic literacy ability category, $13 \%$ of students are in the medium category, and 52\% of students are in the low category, with different achievement in each capability category viewed from three indicators of statistical literacy ability. They are Formulating problems ability; Using concepts ability, facts, procedures and reasoning; Interpreting problems solving ability.
\end{abstract}

Keywords: Statistical literacy ability, student of mathematics education

\section{PENDAHULUAN}

Statistik merupakan cabang ilmu matematika terapan yang terdiri dari teori dan metode mengenai bagaimana cara mengumpulkan, mengukur, mengklasifikasi, menghitung, menjelaskan, mensintesis, menganalisis, dan menafsirkan data yang diperoleh secara sistematis (Ruseffendi, 1993).

Pentingnya mahasiswa mempelajari statistik adalah membantu dalam membaca data yang telah terkumpul sehingga dapat mengambil keputusan yang tepat, untuk melihat perbedaan antara kelompok yang teliti, melihat hubungan antar variabel. Statistik dapat berguna dalam penyusunan model, perumusan hipotesis, pengembangan alat pengambil data, penyusunan rancangan penelitian, penentuan sampel, dan analisis data, yang kemudian data tersebut diinterpretasikan sehingga bermakna. Begitu pentingnya statistik untuk mahasiswa yang akan menempuh skripsi karena dalam penyusunan model, perumusan hipotesis, pengembangan alat pengambil data, penyusunan rancangan penelitian, penentuan sampel, dan analisis data harus tepat. Jika mahasiswa menggunakan metode yang kurang atau bahkan tidak tepat maka interpretasi data menjadi tidak bermakna, sehingga penelitian mereka menjadi sia-sia.

Sebagai upaya pencapaian kebermaknaan pada proses penelitian yang dilakukan oleh mahasiswa, maka diperlukan kemampuan mahasiswa yang meliputi kemampuan menyusun 
serangkaian pertanyaan yang akan diteliti, merumuskan hipotesis statistik, memecahkan, dan menafsirkan permasalahan yang didasarkan pada konteks yang ada. Secara lebih khusus pada bidang statistika, kemampuan tersebut dapat dikatakan sebagai kemampuan melek statistik atau yang kini dikenal dengan literasi statistis.

$$
\text { Literasi statistis adalah }
$$

kemampuan individu (individual's capacity) untuk mengenal dan memahami peran yang dimainkan matematika dalam kehidupan nyata, untuk mampu memberikan penilaian dan pertimbangan secara tepat, memanfaatkan matematika yang dapat memenuhi kebutuhan seseorang menjadi anggota masyarakat yang konstruktif, peduli, dan mau berfikir. Dalam pengertian ini, literasi statistis digunakan untuk memberi penekanan pada pengetahuan statistis, yang digunakan dalam kehidupan sehari-hari. Untuk mendukung ini semua, pengetahuan dasar dan keterampilan statistis mutlak diperlukan.

Menurut de Lange (Kusumah 2011), literasi statistis tidak sebatas mencakup kemampuan melaksanakan sejumlah cara atau prosedur, dan memiliki pengetahuan dasar statistis yang memungkinkan mahasiswa mampu hidup dalam suatu situasi yang sulit dan cukup dengan hanya yang mereka perlukan. Literasi statistis juga mencakup pengetahuan, metode, dan proses statistis yang dimanfaatkan dalam berbagai konteks yang memberi inspirasi dan membuka wawasan pemikiran. Literasi statistis terfokus pada kemampuan penalaran, berfikir, dan interpretasi, di samping kemampuan-kemampuan statistis lainnya. Definisi literasi statistis tidak sekadar terfokus pada pengetahuan minimal dalam matematika. Literasi tersebut juga mencakup doing mathematics dan menggunakan konsep statistis dalam bidang lainnya dan dalam aspek kehidupan sehari-hari. Dari yang biasa hingga yang tidak biasa, dari yang sederhana hingga yang kompleks. Wardhani, S dan Rumiati (2011) menyebutkan bahwa, "Literasi statistis adalah kemampuan seseorang untuk merumuskan, menerapkan dan menafsirkan matematika dalam berbagai konteks, termasuk kemampuan melakukan penalaran secara statistis dan menggunakan konsep, prosedur, dan fakta untuk menggambarkan, menjelaskan atau memperkirakan suatu kejadian".

Betapa pentingnya kemampuan literasi statistis dimiliki oleh mahasiswa bukan hanya sebatas pada terselesaikannya mata kuliah skripsi, lebih daripada itu, agar lahir lulusan yang berkarakter sebagai pengajar dan peneliti di masa mendatang sesuai harapan civitas akademika. Sehingga perlu dibekali kemampuan-kemampuan yang relevan, salah satunya kemampuan literasi statistis. Untuk mengoptimalkan kemampuan literasi statistis mahasiswa, maka diperlukan upaya awal yakni dengan mendeksripsikan sejauh mana kemampuan literasi statistis mahasiswa jurusan pendidikan matematika. Tujuan penelitian ini adalah untuk mendeskripsikan dan mengkaji kemampuan literasi statistis. Dengan mengetahui kemampuan literasi statistis sejak dini pada semester I, maka akan dapat dikembangkan lebih lanjut realisasi dari keadaan subjek yang sedang diteliti pada mata kuliah statistika lebih lanjut.

\section{METODE PENELITIAN}

Metode yang digunakan dalam penelitian ini adalah metode kualitatif deskriptif dengan jenis strategi penelitian yaitu jenis studi kasus. Penelitian ini dilaksanakan di Jurusan 
Pendidikan Matematika FKIP Universitas Sultan Ageng Tirtayasa. Populasi sekaligus sampel dalam penelitian ini adalah mahasiswa Jurusan
Pendidikan Matematika Semester I Tahun Akademik 2016/2017. Kriteria pencapaian kemampuan literasi statistis sebagai berikut.

Tabel 1. Kriteria Pencapaian Kemampuan Literasi Statistis

\begin{tabular}{|l|c|}
\hline \multicolumn{1}{|c|}{ Skor } & Kemampuan Literasi statistis \\
\hline $\mathrm{s}>70$ & tinggi \\
\hline $60 \leq \mathrm{s} \leq 70$ & sedang \\
\hline $\mathrm{s}<60$ & rendah \\
\hline
\end{tabular}

Dalam penelitian ini peneliti merupakan instrumen utama. Selain itu, instrumen tes kemampuan literasi statistis. Instrumen tes kemampuan literasi statistis meliputi 3 butir pertanyaan dengan indikator 1) Mampu merumuskan masalah , 2) Mampu menggunakan konsep, fakta, prosedur dan penalaran, 3) Menafsirkan (interpret) masalah untuk memecahkan masalah. PISA (Wardhani, S dan Rumiati, 2011) mentransformasikan prinsip-prinsip literasi statistis menjadi tiga komponen yaitu komponen konten, proses dan konteks. Adapun komponen konten dalam penelitian ini meliputi ketidakpastian data. Komponen proses meliputi Mampu merumuskan hipotesis, Mampu menggunakan konsep, fakta, prosedur dan penalaran untuk membuktikan hipotesis, Menafsirkan (interpret) masalah dalam kesimpulan, serta komponen konteks yaitu konteks ilmu pengetahuan (scientific).

Teknik analisis data kualitatif yang dilakukan mengacu pada pendapat Bogdan yang meliputi; 1) reduksi data, 2) penyajian data, dan 3) verifikasi. Bogdan menyatakan bahwa analisis data adalah proses mencari dan menyusun secara sistematis data yang diperoleh dari hasil wawancara, catatan lapangan, dan bahan-bahan lain sehingga dapat mudah dipahami dan temuannya dapat diinformasikan kepada orang lain (Sugiyono, 2010). Reduksi data. Mereduksi data berarti merangkum, memilih hal-hal yang pokok, memfokuskan pada hal-hal yang penting, dicari tema dan polanya dan membuang yang tidak perlu. Hasil tes literasi statistis yang telah dikumpulkan menjadi data yang akan dianalisis. Tahap reduksi data dalam penelitian ini meliputi: 1) menyelesaikan soal tes literasi statistis; 2) Mengoreksi hasil tes; 3) Menganalisis hasil tes. Penyajian data. Dalam penelitian ini, penyajian data dilakukan dalam bentuk teks deskriptif, tabel, gambar dan diagram. Dengan menyajikan data, maka akan memudahkan untuk memahami apa yang terjadi, merencanakan kerja selanjutnya berdasarkan apa yang telah dipahami tersebut. Dalam penelitian ini, penyajian data meliputi menyajikan hasil tes dalam tabel dan diagram. Dari hasil penyajian tersebut selanjutnya didapat kesimpulan berupa data temuan sehingga dapat dideskripsikan dan dapat menjawab permasalahan dalam penelitian ini. Langkah ketiga dalam penelitian ini adalah penarikan kesimpulan dan verifikasi. Verifikasi dlam penelitian ini dilakukan dengan cara membandingkan hasil tes. Selanjutnya ditarik kesimpulan tentang profil literasi statistis mahasiswa.

\section{HASIL PENELITIAN DAN PEMBAHASAN \\ Pengolahan data kualitatif dilakukan dengan menggunakan}


ISSN 2089-8703 (Print) Vol. 6, No. 2 (2017)

ISSN 2442-5419 (Online)

Microsoft Office Excel 2010 untuk

Berikut statistika deksripsi kemampuan menghitung presentase kemampuan

literasi statistis secara keseluruhan.

literasi statistis secara keseluruhan.

Tabel 2. Statistik Deskriptif Kemampuan Literasi Statistis

\begin{tabular}{|c|c|}
\hline Jumlah subyek & 107 \\
\hline Rata-rata & 62 \\
\hline Simpangan baku & 23 \\
\hline Skor tertinggi & 100 \\
\hline Skor terendah & 10 \\
\hline
\end{tabular}

Berdasarkan data rata-rata dan simpangan baku di atas, dapat dikelompokkan kategori kelompok subyek penelitian pada kemampuan literasi staitistis tinggi, sedang dan rendah. Dari kategori kemampuan literasi statistis mahasiswa, diperoleh hasil sebanyak 37 mahasiswa berada pada kategori tinggi, 14 mahasiswa berada pada kategori sedang, dan 56 mahasiswa berada pada kategori rendah. Adapun presentasi tiap kategori yaitu $35 \%$ mahasiswa berada pada kategori tinggi, $13 \%$ mahasiswa berada pada kategori sedang, dan 52\% mahasiswa berada pada kategori rendah, secara lebih jelas ditampilkan pada diagram berikut.

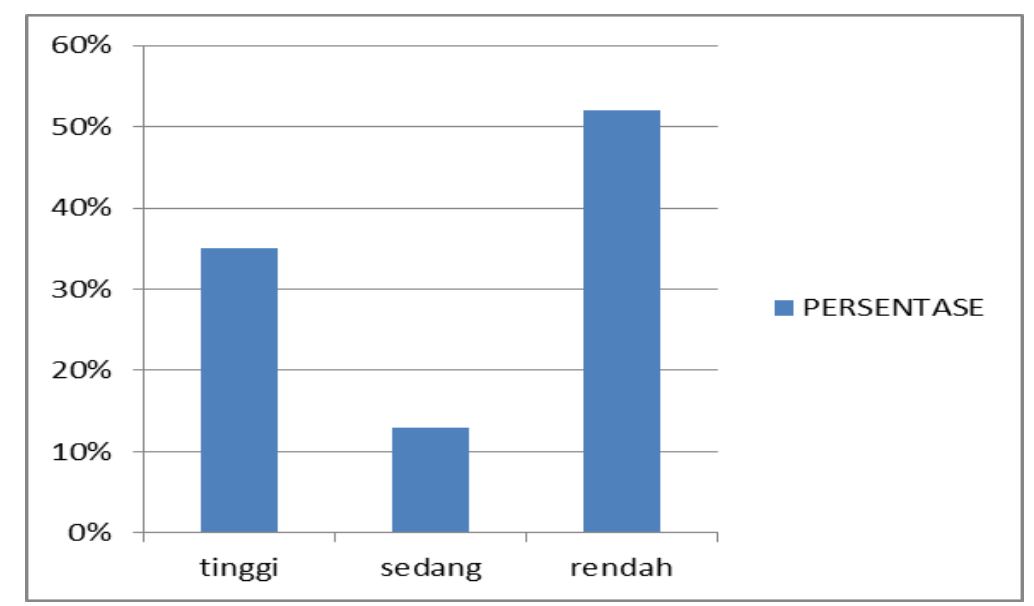

Gambar 1. Persentase Kategori Kemampuan Literasi Statistis

\begin{abstract}
Berdasarkan diagram di atas, nampak bahwa sebagain besar mahasiswa berada pada kategori literasi kategori rendah. Untuk memperoleh gambaran kemampuan literasi pada setiap kategori, sehingga dianalisis jawaban tes kemampuan literasi statistis dideskripsikan sesuai dengan kategori kemampuan literasi yang terdiri dari tiga kategori yaitu: 1) Kemampuan
\end{abstract}

literasi kategori tinggi, 2) kemampuan literasi statistis kategori sedang, 3) Kemampuan literasi statistis kategori rendah dideskripsikan sebagai berikut.

1. Kemampuan literasi kategori tinggi Berikut hasil jawaban mahasiswa dengan kemampuan literasi kategori tinggi pada indikator kemampuan merumuskan hipotesis 
ISSN 2089-8703 (Print) Vol. 6, No. 2 (2017)

ISSN 2442-5419 (Online)
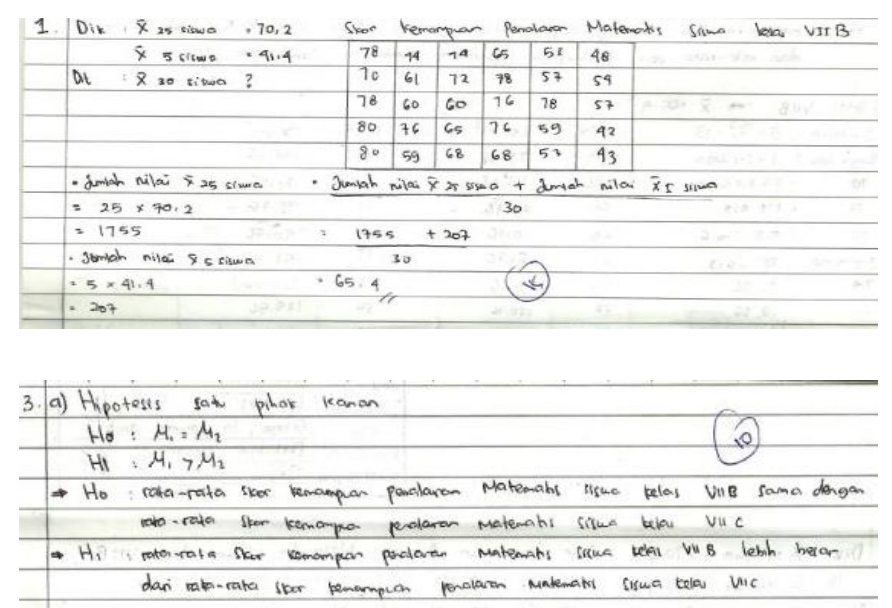

Gambar 2. Jawaban nomor 1

Subyek mampu mengidentifikasi kecukupan data dalam soal, hal ini dibuktikan dengan jawaban subyek yang sudah mampu menerapkan rumus rata-rata gabungan, dengan mencari rata-rata pada masing-masing permasalahan, dan dilajutkan dengan mencari rata-rata gabungan. Subyek sudah benar dalam merumuskan hipotesis tetapi tidak lengkap, hal ini ditunjukkan dengan mampu merumuskan masalah dalam bentuk hipotesis statistik satu pihak kanan dengan tepat, dan mampu menuliskan hipotesis penelitian dengan tepat. Antara hipotesis statistik dan hipotesis penelitian sudah dijabarkan dengan sesuai, namun tidak memberikan penjelasan lebih rinci keterangan pada rata-rata 1 dan rata-rata II yang menggambarkan dua kelas tersebut.

Berikut hasil jawaban mahasiswa pada indikator kemampuan menggunakan konsep, fakta, prosedur dan penalaran untuk membuktikan hipotesis

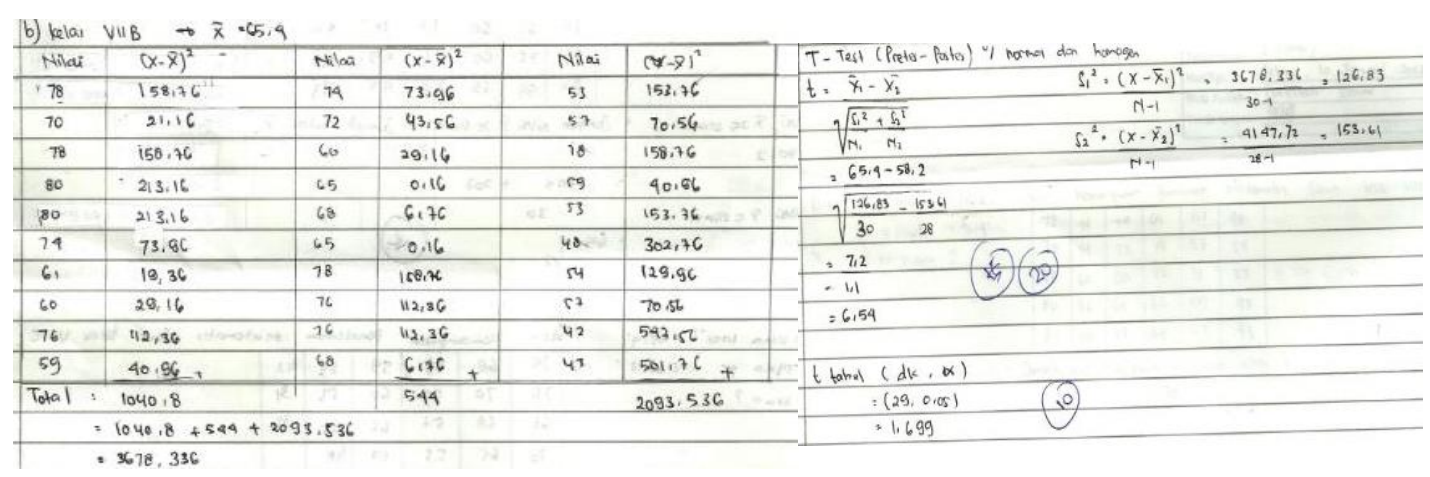

Gambar 3. Jawaban nomor 2

Berdasarkan jawaban di atas, identifikasi yang dilakukan subyek hanya menunjukkan sedikit pemahaman terkait uji hipotesis yang dilakukan, pemilihan uji yang ditunjukkan sudah tepat yakni menggunkan t-test untuk uji beda dua mean data tidak berpasangan, hanya saja dalam pemilihan rumus uji $\mathrm{t}$ belum tepat yakni menggunakan rumus the separate model t-test, padahal kondisi soal dengan jumlah data yang berbeda pada dua kelompok, dan sampel homogen, uji hipotesis mengunakan the pooled variance model 
t-test. Dalam penentuan derajat kebebasan (dk), subyek keliru dengan menuliskan besar derajat kebebasan 29, seharusnya kondisi soal dengan jumlah data berbeda dan sampel homogen, maka $\mathrm{dk}=\mathrm{n}_{1}+\mathrm{n}_{2}-2$. Dengan demikian, jumlah kelas pertama sebanyak 30 siswa, dan kelas kedua 28 siswa, maka derajat kebebasan seharusnya yaitu 56 .

Berikut hasil jawaban mahasiswa dengan kemampuan literasi kategori tinggi pada indikator menafsirkan (interpret) masalah dan menuliskan kesimpulan:

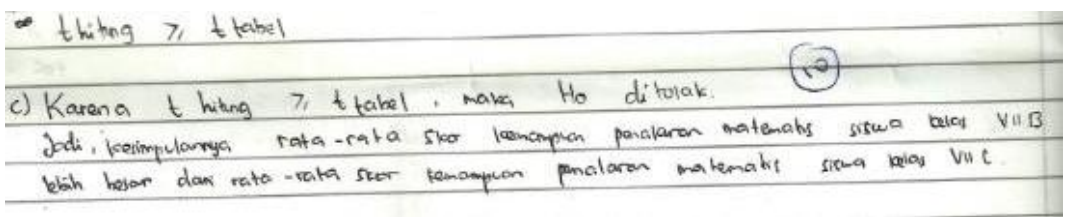

Gambar 4. Jawaban nomor 3

Berdasarkan gambar di atas, subyek memberikan ilustrasi dengan menafsirkan kondisi hasil perhitungan, subyek sudah memahami kriteria pengujian hipotesis yaitu kondisi penolakan hipotesis.
2. Kemampuan literasi statistis kategori sedang

Berikut hasil jawaban mahasiswa dengan kemampuan literasi kategori sedang pada indikator kemampuan merumuskan hipotesis

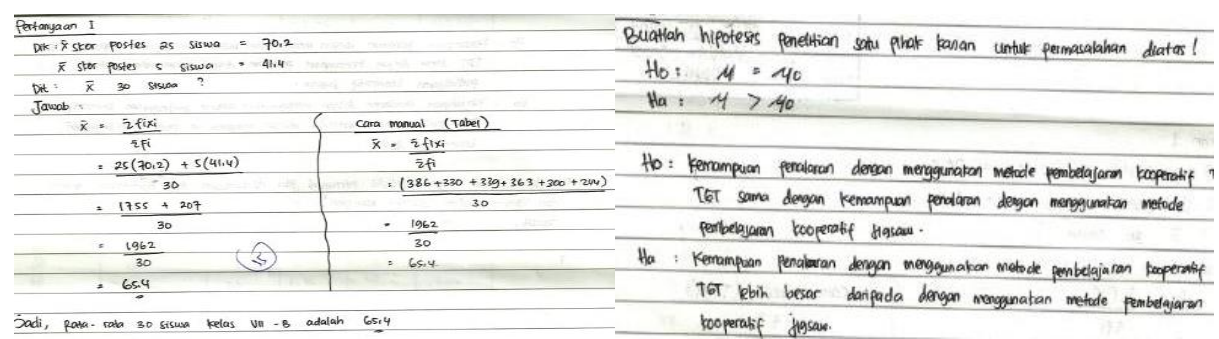

Gambar 5. Jawaban nomor 1

Subyek mampu mengidentifikasi kecukupan data dalam soal, hal ini dibuktikan dengan jawaban subyek yang sudah mampu menerapkan rumus rata-rata gabungan, dengan mencari rata-rata pada masing-masing permasalahan, dan dilajutkan dengan mencari rata-rata gabungan. Bahkan untuk membuktikan jawaban, subyek memeriksa kembali hasil dengan melakukan perhitungan secara manual dengan menggunakan data pada tabel yang diberikan. Subyek sudah benar dalam merumuskan hipotesis tetapi tidak lengkap, hal ini ditunjukkan dengan mampu merumuskan masalah dalam bentuk hipotesis statistik satu pihak kanan dengan tepat, dan mampu menuliskan hipotesis penelitian dengan tepat. Antara hipotesis statistik dan hipotesis penelitian sudah dijabarkan dengan sesuai, namun pemilihan simbol rata-rata yang dituliskan kurang relevan untuk dibandingkan serta tidak memberikan penjelasan lebih rinci keterangan pada rata-rata 1 dan rata-rata II yang menggambarkan dua kelas tersebut. 
ISSN 2089-8703 (Print) Vol. 6, No. 2 (2017)

ISSN 2442-5419 (Online)

Berikut hasil jawaban
mahasiswa pada indikator
kemampuan menggunakan konsep,
fakta, prosedur dan penalaran untuk
membuktikan hipotesis.

\begin{tabular}{|c|c|c|c|c|c|c|}
\hline Datia . Wi-B & Data $\mathrm{VII}-\mathrm{C}$ & $\left(x-\bar{x}_{0}\right)$ & $\left(x \cdot \overline{x_{a}}\right)^{2}$ & $\left(x-\bar{x}_{b}\right)$ & $\overline{\left(x-x_{b}\right)}$ & $S_{A}, 2(x-\pi)^{2}$ \\
\hline 42 & 32 & $-23,4$ & 547.56 & $-26,2$ & 686646 & $a-1$ \\
\hline 43 & 34 & $-22,4$ & 501.76. & $-24,2$ & 585.64 & $=\frac{3715,2}{32}$ \\
\hline 48 & 56 & $-17+4$ & 302,76 & $-22,2$ & 492.84 & $\frac{29}{128,4}$ \\
\hline 53 & 42 & $-12,4$ & 153,76 & $-16,2$ & 26.44 & 128.11 \\
\hline S3. & 45 & $-12,4$ & 153.76 & -13.2 & 194.24 & 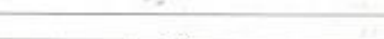 \\
\hline 54 & 48 & $-11,4$ & $139, \%$ & $-10,2$ & 104,04 & $S_{L}=\sum_{2}\left(x-\overline{x_{\varepsilon}}\right)^{2}$ \\
\hline 57 & 52 & $-8,4$ & 70,56 & $-6+2$ & $38,44-7$ & $n-1$ \\
\hline 57 & 53 & $-8+4$ & 70,56 & $-5,2$ & 27.04 & \multirow{2}{*}{ Ftolbel $\alpha=5 \%=0,05$. } \\
\hline 59 & 53. & $-6,4$ & 40,96 & $-5,2$ & 27.04 & \\
\hline 59 & $\$$. & $-6,4$ & 40.86 & $-5,2$ & 27.04 & $d k_{A}=30-1=29$. \\
\hline$\frac{60}{60}$ & $\frac{97}{57}$ & $\frac{-5,4}{-5,4 .}$ & \begin{tabular}{|l|}
29,16 \\
29,16 \\
\end{tabular} & $\frac{-1.2}{-1.2}$ & $\frac{1.44}{1,44}$ & \multirow{2}{*}{$d k_{B}=28-1=27}$. \\
\hline 61 & 59 & $-4,4$ & 19,36 & 0,8 & 0.64 & \\
\hline 65 & 59 & $-0,4$ & 0.16 & 0,8 & 0.64 & \\
\hline 65 & 59 & $-8,4$ & 0.16 & 0.8 & 0.64 & * 29 terktak antara 24 dan 30 \\
\hline 68 & 60 & $2 k$ & 6.76 & 1.8 & 3,24 & $f(2127)=\log 3$ \\
\hline 68 & 60 & 2,6 & 6.76 . & 1.8 & 3,24. & $f($ sa27) $=1,8$ \\
\hline 70 & +8 & 4,6 & 21.16. & 68 & $46,24$. & $I=0.05 \quad x(29-24)$ \\
\hline 72 & 66. & 66 & 43,56 . & 7.8 & 60,84 & 6 \\
\hline 74 & $2=$ & 8.6 & 73,96 . & $9,8$. & 96,04 & $=0,25=0,0416$. \\
\hline 34 & 68 & 816 & 73,36 & 2,8 & 96,04 & \multirow{2}{*}{ f hitung $=1,18$} \\
\hline 76 & 68 & $10 \cdot 6$ & 112,36 . & 9,8 & $20,04=$ & \\
\hline 36 & 70 & 10.6 & 112,36 & 11,8 & 139.24 & \multirow{2}{*}{ I tabel $=1,88$} \\
\hline 76 & 70 & 10,6 & 112,36 & 11,8 & 139,24 & \\
\hline$\frac{78}{78}$ & $\frac{72}{72}$ & $\frac{12.6}{1216}$ & $\begin{array}{l}158.76 \\
158.76\end{array}$ & 13.8 & $\frac{190,44}{190,144}$ & \multirow{2}{*}{ Make: f hiturng $\angle$ \& tabel } \\
\hline 78 & 75 & 126 & \begin{tabular}{|l}
188.76 \\
18.76 \\
\end{tabular} & \begin{tabular}{|l|}
13.8 \\
16.6 \\
\end{tabular} & $\frac{1920,4}{282,24}$ & \\
\hline 78 & 76 & 12.6 & 188.76 & 17,8 & 316,84 & \multirow{2}{*}{ Maka kezmpulannya to ditolak } \\
\hline 80 & & 14,6 & $2,3,16$ & & & \\
\hline 80 & & 14.6 & 23.16 & atsing & 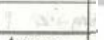 & \multirow[t]{2}{*}{$p$} \\
\hline 1962 & 1629 & & 3715,2 & 85 & 9090,12 & \\
\hline
\end{tabular}

Gambar 6. Jawaban nomor 2

Berdasarkan jawaban di atas, subyek menggunakan informasi yang tidak relevan nampak dari ketidakpahaman terkait uji beda dua mean untuk data tidak berpasangan, subyek gagal mengidentifikasi bagian yang penting dalam soal untuk melakukan uji hipotesis jika telah diketahui bahwa data diasumsikan berdistribusi normal dan varians kedua sampel homogen. Strategi yang digunakan tidak tepat, nampak pada pemilihan uji statistik yang digunakan dengan menggunakan uji homogenitas fisher. Jawaban yang ditampilkan tidak sistematis, nampak dari adanya penyelesaian dengan menggunakan rumus separated variance, walaupun penjabaran rumus terdapat kesalahan. Dalam penentuan derajat kebebasan (dk), subyek salah dalam menentukan rumus derajat kebebasan yang digunakan, dengan menuliskan $\mathrm{dk}$ pembilang dan $\mathrm{dk}$ penyebut. Pada indikator menafsirkan (interpret) masalah dan menuliskan kesimpulan subyek tidak mampu menafsirkan masalah dan belum memahami kriteria pengujian hipotesis.

3. Kemampuan literasi statistis kategori rendah dideskripsikan sebagai berikut. 
ISSN 2089-8703 (Print) Vol. 6, No. 2 (2017)

ISSN 2442-5419 (Online)

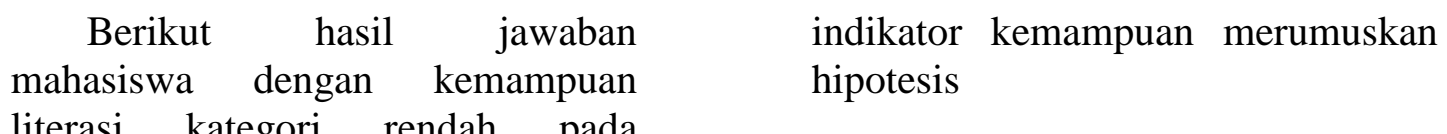

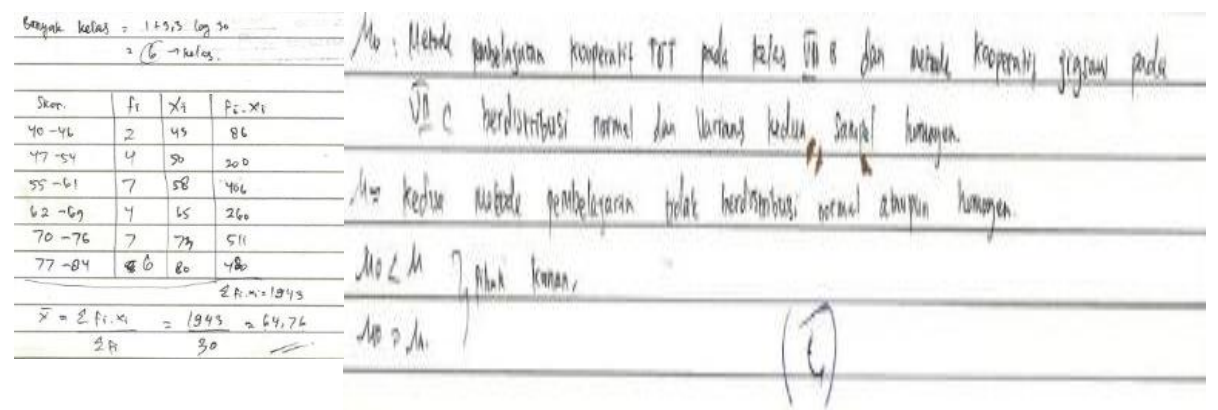

Gambar 7. Jawaban nomor 3

Subyek belum mampu mengidentifikasi kecukupan data dalam soal, hal ini nampak dari jawaban subyek tidak mampu menerapkan rumus rata-rata gabungan, subyek hanya melakukan perhitungan secara manual dengan menggunakan data pada tabel yang diberikan.

Subyek belum mampu merumuskan hipotesis, hal ini nampak dari jawaban yang ditunjukkan yaitu salah dalam menuliskan hipotesis statistik satu pihak kanan, dan salah dalam menuliskan penjelasan dari simbol rata-rata yang dituliskan.

Berikut hasil jawaban mahasiswa pada indikator kemampuan menggunakan konsep, fakta, prosedur dan penalaran untuk membuktikan hipotesis.

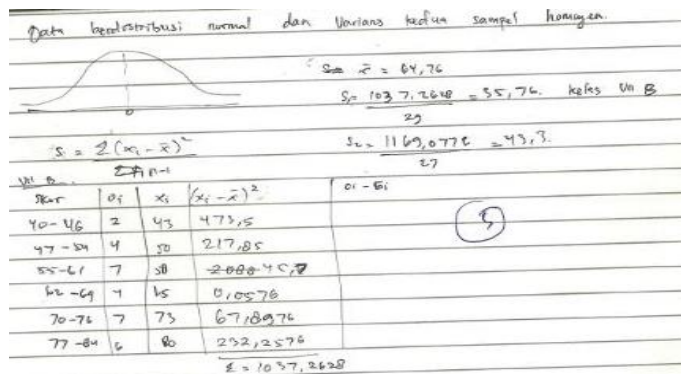

Gambar 8. Jawaban nomor 3

Berdasarkan jawaban di atas, subyek menggunakan informasi yang tidak relevan nampak dari ketidakpahaman terkait uji beda dua mean untuk data tidak berpasangan, subyek gagal mengidentifikasi bagian yang penting dalam soal untuk melakukan uji hipotesis jika telah diketahui bahwa data diasumsikan berdistribusi normal dan varians kedua sampel homogen. Strategi yang digunakan tidak utuh, nampak pada jawaban mahasiswa hanya sebatas mencari simpangan baku untuk masingmasing kelas. Pada indikator menafsirkan (interpret) masalah dan 
menuliskan kesimpulan subyek tidak mampu menafsirkan masalah karena tidak menuliskan jawaban pada lembar jawaban.

Berdasarkan deskripsi di atas, kemampuan literasi statistis mahasiswa semester I jurusan pendidikan matematika Universitas Sultan Ageng Tirtayasa sebagian besar berada pada kategori kemampuan literasi rendah, hal ini dilihat dari persentase capaian mahasiswa setelah menyelesaikan tes literasi statistis, 52\% mahasiswa berada pada kategori kemampuan literasi statistis rendah. Berdasarkan analisis jawaban mahasiswa pada tiga kategori, kemampuan mahasiswa dalam literasi statistis masih sangat lemah, sehingga perlu diupayakan strategi untuk meningkatkan kemampuan literasi statistis.

Kemampuan literasi statistis merupakan kemampuan yang penting dimiliki di era digitalisisi. Literasi statistik adalah seperangkat kemampuan untuk memahami statistik. Gal (2002) menyatakan bahwa, literasi statistis meliputi kemampuan untuk menginterpretasi, mengevaluasi kritis, dan mengkomunikasikan informasi dan pesan statistis. Melek statistik diperlukan bagi warga negara agar dapat memahami materi yang dipublikasikan oleh media seperti televisi, koran dan situs-situs internet. Dalam hal ini, kemampuan berhitung merupakan syarat utama dalam literasi statistik.

Dalam rangka menghasilkan lulusan jurusan pendidikan matematika yang memiliki kemampuan literasi statistis yang memadai, agar dapat dimanfaatkan dalam kehidupannya, maka diperlukan proses pembelajaran terkait analisis data statistis kepada mahasiswa sedini mungkin. Di beberapa negara, seperti Amerika Serikat dan Australia, siswa sudah diperkenalkan dengan statistika sejak usia sekitar sepuluh tahun (ACE,1991; NCTM, 2000). Di Belanda siswa mulai diperkenalkan dengan statistika deskriptif pada usia sekitar 13 tahun. Hal ini, jelas untuk menumbuhkan literasi statistis berdasarkan data empiris dari beberapa negara tersebut berkisar antara usia 10 sampai 14 tahun.

Salah satu solusi untuk meningkatkan kemampuan literasi statistis melalui strategi yang digunakan oleh dosen dalam pembelajaran, Moore (1997) menyarankan sebuah synergy antara content-pedagogytechnology.Dalam Content-pedagogy meliputi: Analisisis data-lembar kerja, Statistika praktis-komunikasi, kooperatif, Konsep-menjelaskan, bukti. Dalam Pedagogyptechnology meliputi: Visualisasi (multi representasi)-Grafik automata, Pemecahan masalahperhitungan automata, Belajar aktifmultimedia. Dalam Technology-content meliputi: Komputasi-analisis data, diagnostik, Automatisasi-perluasan konsep, Simulasi-alternatif untuk pembuktian

\section{KESIMPULAN DAN SARAN}

Berdasarkan hasil penelitian dan pembahasan dapat disimpulkan bahwa:

1. $35 \%$ mahasiswa berada pada kategori kemampuan literasi statistis tinggi, $13 \%$ mahasiswa berada pada kategori sedang, dan 52\% mahasiswa berada pada kategori rendah.

2. Kemampuan literasi statistis kategori tinggi

Subyek sudah benar dalam merumuskan hipotesis tetapi tidak lengkap, identifikasi yang dilakukan subyek hanya menunjukkan sedikit pemahaman terkait uji hipotesis yang dilakukan, subyek memberikan ilustrasi dengan menafsirkan kondisi hasil perhitungan, subyek sudah memahami kriteria pengujian 
hipotesis yaitu kondisi penolakan hipotesis.

3. Kemampuan literasi statistis kategori sedang

Subyek sudah benar dalam merumuskan hipotesis tetapi tidak lengkap, subyek menggunakan informasi yang tidak relevan nampak dari ketidakpahaman terkait uji beda dua mean untuk data tidak berpasangan, subyek gagal mengidentifikasi bagian yang penting dalam soal, subyek tidak mampu menafsirkan masalah dan belum memahami kriteria pengujian hipotesis.

4. Kemampuan literasi statistis kategori rendah.

Subyek belum mampu merumuskan hipotesis, subyek menggunakan informasi yang tidak relevan nampak dari ketidakpahaman terkait uji beda dua mean untuk data tidak berpasangan, pada indikator menafsirkan (interpret) masalah dan menuliskan kesimpulan subyek tidak mampu menafsirkan masalah karena tidak menuliskan jawaban pada lembar jawaban.

Saran dari penelitian ini adalah

1. Pembelajaran yang dilaksanakan harus mengakomodasi kemampuan mahasiswa baik mahasiswa kategori tinggi, sedang dan rendah terutama pada indikator menggunakan konsep, fakta dan prosedur dan penalaran.

2. Dosen perlu menggunakan strategi pembelajaran kontekstual agar dapat meningkatkan kemampuan merumuskan masalah, menggunakan konsep, fakta, prosedur dan penalaran, serta kemampuan menafsirkan (interpret) masalah untuk memecahkan masalah.
DAFTAR PUSTAKA

ACE. 1991. A National Statement on Mathematics for Australian Schools. Carlton, Vic, Australian: Curriculum Corporation.

Gal, I. 2002. Adult's Ststistical Literacy: Meanings, Components, Responsibilities. International Statistical Review. Vol. 70, No.1, Hal 151.

Kusumah, Y. S. 2011. Literasi Statistis. Disajikan pada Seminar Nasional Matematika, Universitas Bandar Lampung.

Moore, D. 1997. New Pedagogy and New Content: The Case of statistics. International Statistical Review. Vol. 65, No 2, Hal 123-165.

NCTM [National Council of Teachers of Mathematics]. 2000. Principles and Standards for School Mthematics.Virginia: NCTM.

Ruseffendi. 1993. Statistika Dasar untuk Penelitian Pendidikan. Jakarta: Dirjen Dikti, Depdikbud.

Sugiyono. 2010. Metode Penelitian Kuantitatif Kualitatif \& RND. Bandung : Alfabeta.

Wardhani, S dan Rumiati. 2011. Instrumen Penilaian Hasil Belajar Matematika SMP; Belajar dari PISA dan TIMSS. Yogyakarta: Kemdiknas, P4TK Matematika. 